\title{
Megamonas rupellensis sp. nov., an anaerobe isolated from the caecum of a duck
}

Correspondence

Eric Rosenfeld

eric.rosenfeld@univ-Ir.fr
The microbial composition of the chicken intestine evolves with age and varies in its different sections. It is estimated that $60-90 \%$ of the intestinal bacterial community can not currently be cultivated ( $\mathrm{Lu}$ et al., 2003). The dominant micro-organisms in the gut include bacteria related to Clostridium, Lactobacillus, Bacteroides and Megamonas (Lan et al., 2002; Zhu et al., 2002). This complex microflora is known to play a key role in the health of birds. For instance, young chickens are very sensitive to enteropathogen infections because their intestinal micro-organisms are not fully established (Nurmi \& Rantala, 1973). In 2000, searching for bacteria that produce anti-enteropathogen molecules, Portrait et al. (2000) isolated an anaerobic strain $\left(\mathrm{FM} 1025^{\mathrm{T}}\right)$ from the caecum of a duck. This strain was preliminarily identified as Fusobacterium mortiferum using API galleries. In the present work, we have characterized this bacterium further and, using $16 \mathrm{~S}$ rRNA gene sequence analysis, we have shown that strain $\mathrm{FM} 1025^{\mathrm{T}}$ represents a novel species belonging to the genus Megamonas (Shah \& Collins, 1982).

Strain $\mathrm{FM} 1025^{\mathrm{T}}$ was grown routinely at $37{ }^{\circ} \mathrm{C}$ on TGY broth (w/v; $3 \%$ tryptone, $2 \%$ yeast extract, $0.5 \%$ glucose, $0.05 \%$ L-cysteine hydrochloride) using either anaerobic jars (AnaeroGen; Oxoid) or an anaerobic chamber containing $10 \% \mathrm{H}_{2}, 10 \% \mathrm{CO}_{2}$ and $80 \% \mathrm{~N}_{2}$ (MACS DG500; Don Whitley Scientific). Strain $\mathrm{FM} 1025^{\mathrm{T}}$ was

The GenBank/EMBL/DDBJ accession number for the 16S rRNA gene sequence of strain FM1025 ${ }^{\top}$ is EU346729. restreaked weekly onto TGY agar [TGY broth solidified with $1.2 \%(\mathrm{w} / \mathrm{v})$ agar] and could be stored for several years after mixing $0.5 \mathrm{ml}$ of an overnight culture with $0.5 \mathrm{ml}$ $30 \%(\mathrm{w} / \mathrm{v})$ glycerol. Unless otherwise specified, growth of strain $\mathrm{FM} 1025^{\mathrm{T}}$ was tested in $250 \mathrm{ml}$ TGY broth incubated at $37^{\circ} \mathrm{C}$ under continuous stirring (160 r.p.m.) in the anaerobic chamber.

Strain FM $1025^{\mathrm{T}}$ grew optimally at $37{ }^{\circ} \mathrm{C}$ and the $\mathrm{pH}$ range for growth was $\mathrm{pH} 5-9$ with an optimum at $\mathrm{pH}$ 7. On solid M63 minimal medium (Miller, 1972) supplemented with the reducing amino acid L-cysteine hydrochloride $(0.05 \%$ $\mathrm{w} / \mathrm{v})$, no colonies were observed after $72 \mathrm{~h}$ of incubation. In the same medium enriched with $0.2 \%$ yeast extract, colonies could be visualized after $48 \mathrm{~h}$ of incubation. Strain FM1025 ${ }^{\mathrm{T}}$ was anaerobic, non-motile and oxidase- and catalase-negative.

After growth on solid medium or in liquid broth for 12, 24 or $48 \mathrm{~h}$, cultures were Gram-negative to Gram-variable. The strain was unsporulated in TGY but intracellular inclusions could be seen on Gram stain preparations. For electron microscopy, $5 \mathrm{ml}$ aliquots of a $48 \mathrm{~h}$ culture were centrifuged for $5 \mathrm{~min}$ at $5000 \mathrm{~g}$. Cell pellets were washed twice with $50 \mathrm{mM}$ sodium cacodylate buffer $(\mathrm{pH} 7)$ and prepared as described by Dongard \& Bordes (1991). The preparations were examined using a Philips Quanta 200 ESEM/FEG microscope with an Everhart Thornley-BSE detector. Cells were rod-shaped $(1.0-6.0 \mu \mathrm{m})$ and occurred singly, in pairs and in filaments in liquid cultures (Fig. 1). Longer filaments were observed in solid cultures. 

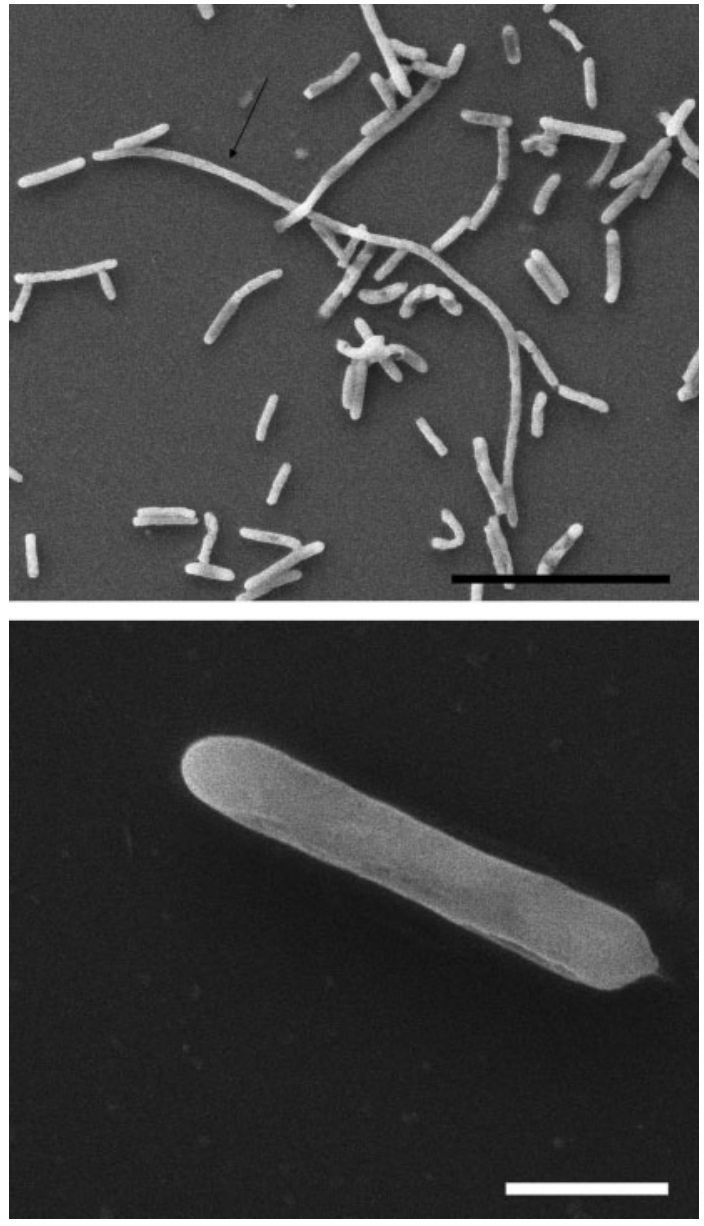

Fig. 1. Scanning electron micrographs of cells of strain $\mathrm{FM} 1025^{\top}$ grown anaerobically for $48 \mathrm{~h}$ in TGY broth. The arrow indicates a filamentous structure. Bars, $20 \mu \mathrm{m}$ (top) and $2 \mu \mathrm{m}$ (bottom).

DNA was prepared as described by Marmur (1961) and the $\mathrm{G}+\mathrm{C}$ content of the DNA was determined by HPLC (Carlotti et al., 1993). The 16S rRNA gene was amplified by PCR using primers Fpnal (5'-AAGTCGAACGGGGTGTTTA- $3^{\prime}$ ) and RPna2 (5'-CAAACCCGAAGCCGGCTG$\left.3^{\prime}\right)$. Amplified DNA fragments were purified using the Qiagen PCR purification kit and both strands were sequenced on an ABI 310 sequencer (Applied Biosystems) using the 16S rRNA full gene sequencing kit from ABI. For identification of closest relatives, the sequence of strain FM1025 $5^{\mathrm{T}}$ was compared to $16 \mathrm{~S}$ rRNA gene sequences in GenBank using BLASTN version 2.2.17 (Altschul et al., 1997). Sequence alignment was performed using CLUSTAL W. Phylogenetic trees were constructed using PAUP 4.0, on 1399 base comparisons using the neighbourjoining method and bootstrap values of 1000 replicates. The sequence of the 16S rRNA gene determined for strain FM1025 ${ }^{\mathrm{T}}$ (1399 nt) placed it near the genus Megamonas within the phylum Firmicutes, in the lineage Clostridia, Clostridiales, Acidaminococcaceae (Morotomi et al., 2007).
The closest relatives were Megamonas hypermegale DSM $1672^{\mathrm{T}}$, at $94.9 \%$ similarity and 71 nucleotide differences, and the recently described Megamonas funiformis YIT $11815^{\mathrm{T}}$ (Sakon et al., 2008), at $97.6 \%$ similarity and 29 nucleotide differences. The $100 \%$ bootstrap value observed strongly supports the grouping of $\mathrm{FM} 1025^{\mathrm{T}}$ with Megamonas hypermegale, the type species of the genus (Cato \& Barnes, 1976; Harrisson \& Hansen, 1963; Shah \& Collins, 1982). Sequence similarity of less than $91 \%$ was observed with representative type strains of Pectinatus and Selenomonas species (Fig. 2).

This difference in $16 \mathrm{~S}$ rRNA gene sequence suggests a phylogenetic difference sufficient to assign strain FM1025 to a novel species in the genus Megamonas. This is supported by the DNA G+C content of $33 \pm 2 \mathrm{~mol} \%$ (Shah \& Collins, 1982). However strain FM1025 $5^{\mathrm{T}}$ (1.0$6.0 \mu \mathrm{m})$ can be easily differentiated from $M$. hypermegale $(2-4.6 \times 11.6-15 \mu \mathrm{m})$ by its smaller cells (Cato \& Barnes, 1976; Harrisson \& Hansen, 1963) and on the basis of an absence of acid production from melezitose and Lrhamnose. It can be differentiated from $M$. funiformis (Sakon et al., 2008) on the basis of the presence of acid production from glycerol and cellobiose. 16S rRNA gene sequence comparisons revealed similarity above $98 \%$ with numerous sequences of uncultured isolates from the caeca of broiler chickens (Bjerrum et al., 2006) or other types of organisms. Strain $\mathrm{FM} 1025^{\mathrm{T}}$ is the first isolate of this taxon to be cultivated and described.

API 20A profiles were analysed after 24 and $48 \mathrm{~h}$ and submitted to bioMérieux for identification. The profiles obtained were similar to those of the Gram-negative Prevotella ruminicola subsp. ruminicola and the Grampositive Actinomyces israelii ( $80.2 \%$ ID in both cases). Sensitivity towards antibiotics was tested using disc assays. A $24 \mathrm{~h}$ culture in TGY broth was diluted to an $\mathrm{OD}_{600}$ of 0.12 as specified by the recommendations of the Comite de l'Antibiogramme of the Societé Française de Microbiologie. TGY agar plates were flooded with $2 \mathrm{ml}$ of this dilution prior to placing the antibiotic discs (Bio-Rad). Inhibition haloes were measured after $24 \mathrm{~h}$ incubation in the anaerobic chamber. Strain $\mathrm{FM} 1025^{\mathrm{T}}$ was resistant to vancomycin at $30 \mu \mathrm{g}$, similar to some Prevotella, Bacteroides and Fusobacterium species and Clostridium innocuum. Strain $\mathrm{FM} 1025^{\mathrm{T}}$ was sensitive to $25 \mu \mathrm{g}$ amoxicillin, $10 \mu \mathrm{g}$ imipenem, $4 \mu \mathrm{g}$ metropnidazole, $30 \mu \mathrm{g}$ chloramphenicol, $20 \mu \mathrm{g}$ amoxicillin and $10 \mu \mathrm{g}$ clavulanic acid.

Static TGY broth cultures $(18 \mathrm{ml})$ were used for fermentation analysis. Anaerobic jars and long glass tubes were preferred to the anaerobic chamber and Erlenmeyer flasks in order to minimize the loss of volatile by-products. Aliquots of cultures $\left(48 \mathrm{~h}, 37^{\circ} \mathrm{C}\right)$ were centrifuged for $5 \mathrm{~min}$ at $7500 \mathrm{~g}$. Culture supernatants were sterile-filtered $(0.22 \mu \mathrm{m})$ and analysed in triplicate using a gas chromatograph (Hewlett Packard 5890A) as described by Erable et al. (2005). Glucose concentration was evaluated by the DNS 


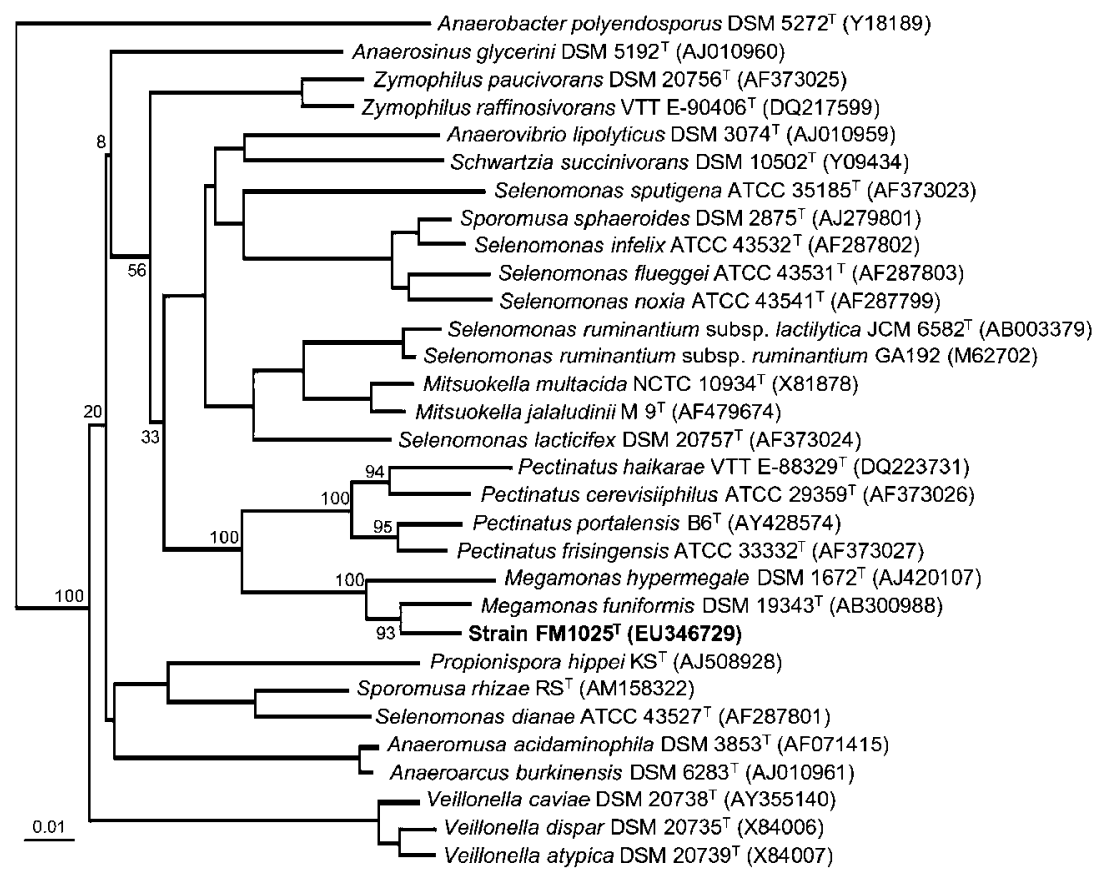

Fig. 2. Phylogenetic tree showing the position of strain $\mathrm{FM} 1025^{\top}$, other species of the 'Acidaminococcaceae' and Megamonas hypermegale DSM $1672^{\top}$, based on $16 \mathrm{~S}$ rRNA gene sequence similarities. The tree was constructed by using the neighbour-joining method, with bootstrap values (reliability values of internal branches) expressed as percentages of 1000 replicates. Accession numbers are shown in parentheses. Bar, $1 \%$ sequence divergence. Anaerobacter polyendosporus DSM $5272^{\top}$ was used as the outgroup. (dinitrosalicylic acid) method (Miller, 1959). We were unable to detect the presence of lactate, propanol, acetone, butyrate, 2,3-butanediol or pentanoate in the supernatant of strain FM1025 $5^{\mathrm{T}}$. Hence, FM $1025^{\mathrm{T}}$ can also be differentiated from $M$. funiformis (Sakon et al., 2008) and $M$. hypermegale (Harrisson \& Hansen, 1963) by the absence of lactate as an end product from TYG broth. Acetate and propionate were the only organic acids detected from glucose fermentation. Propionate appeared to be the major fermentation end product, with a concentration of $25 \mathrm{mM}$ after $48 \mathrm{~h}$ compared with $20 \mathrm{mM}$ for acetate. The initial concentration of glucose was $28 \mathrm{mM}$ and reached $1.3 \mathrm{mM}$ after $72 \mathrm{~h}$ of culture. Considering that $90 \%$ of the glucose consumed $(26.3 \mathrm{mM})$ was converted into end products (the rest being converted into biomass), we assessed that $95 \%$ was fermented into acetate and propionate. This confirmed that acetate and propionate were the major organic acids produced by strain $\mathrm{FM} 1025^{\mathrm{T}}$ in TGY medium. Moreover, the final $\mathrm{pH}$ of cultures was 4.6-4.9, corresponding to the $\mathrm{p} K_{\mathrm{a}}$ of acetate $\left(\mathrm{p} K_{\mathrm{a}}=4.75\right)$ and propionate $\left(\mathrm{p} K_{\mathrm{a}}=4.87\right)$.

\section{Description of Megamonas rupellensis sp. nov.}

Megamonas rupellensis (ru.pel.len'sis. M.L. fem. adj. rupellensis referring to La Rochelle, the site of isolation of the type strain).

Obligately anaerobic, mesophilic, saccharophilic, nonspore-forming, non-motile, Gram-negative or Gram-variable, long rods (1.0-6.0 $\mu \mathrm{m})$. Cells occur singly, in pairs or in chains in liquid medium. Growth occurs in TGY broth within $24 \mathrm{~h}$. On solid medium, colonies are 'ecru' and notched, 10-20 $\mathrm{mm}$ in diameter after 2 days of growth at
$37{ }^{\circ} \mathrm{C}$. End products are acetate and propionate. The $\mathrm{pH}$ for growth is $\mathrm{pH}$ 5.0-9.0, with an optimum at $\mathrm{pH}$ 7.0. Oxidase and catalase activities are absent. Nitrate and nitrite reduction activities are absent. Acids are produced from D-glucose, D-mannitol, D-lactose, sucrose, maltose, salicin, D-xylose, L-arabinose, glycerol, cellobiose, D-mannose, raffinose, D-sorbitol and trehalose, but not from melezitose or L-rhamnose. Resistant to vancomycin $(30 \mu \mathrm{g}$ per disc), but not to amoxicillin $(25 \mu \mathrm{g})$, imipenem $(10 \mu \mathrm{g})$, metronidazole $(4 \mu \mathrm{g})$, chloramphenicol $(30 \mu \mathrm{g})$, amoxicillin $(20 \mu \mathrm{g})$ or clavulanic acid $(10 \mu \mathrm{g})$. The $\mathrm{G}+\mathrm{C}$ content of DNA of the type strain is $33 \pm 2 \mathrm{~mol} \%$.

The type strain, FM1025 $5^{\mathrm{T}}\left(=\mathrm{DSM} 19944^{\mathrm{T}}=\mathrm{CIP} 109788^{\mathrm{T}}\right)$, was isolated from the caecum of a duck in La Rochelle, France.

\section{Acknowledgements}

We thank the Conseil général de la Charente-Maritime for financial support (PhD grant to R. C.). We are grateful to Isabelle Goubet (UMR 6250, CNRS, La Rochelle) for her help with gas chromatography and to Monique Bordes (CCA, La Rochelle) for her help with electron microscopy.

\section{References}

Altschul, S. F., Madden, T. L., Schaffer, A. A., Zhang, J., Zhang, Z., Miller, W. \& Lipman, D. J. (1997). Gapped BLAST and PSI-BLAST: a new generation of protein database search programs. Nucleic Acids Res 25, 3389-3402.

Bjerrum, L., Engberg, R. M., Leser, T. D., Jensen, B. B., Finster, K. \& Pedersen, K. (2006). Microbial community composition of the ileum and cecum of broiler chickens as revealed by molecular and culturebased techniques. Poult Sci 85, 1151-1164. 
Carlotti, A., Meugnier, H., Pommier, M. T., Villard, J. \& Freney, J. (1993). Chemotaxonomy and molecular taxonomy of some coryneform clinical isolates. Zentralbl Bakteriol 278, 23-33.

Cato, E. P. \& Barnes, E. M. (1976). Designation of the neotype strain Bacteroides hypermegas Harrison and Hansen. Int J Syst Bacteriol 26, 494-497.

Dongard, S. \& Bordes, M. (1991). Le vélum de Ruditapes philippinarum (A \& R): comparaison avec $R$. decussatus (L.) et Crassostrea gigas. C R Acad Sci 62, 254-256 (in French).

Erable, B., Goubet, I., Lamare, S., Seltana, A., Legoy, M. D. \& Maugard, T. (2005). Nonconventional hydrolytic dehalogenation of 1 -chlorobutane by dehydrated bacteria in a continuous solid-gas biofilter. Biotechnol Bioeng 91, 304-313.

Harrisson, A. P. \& Hansen, P. A. (1963). Bacteroides hypermegas nov. spec. Antonie van Leeuwenhoek 29, 22-28.

Lan, P. T., Hayashi, H., Sakamoto, M. \& Benno, Y. (2002). Phylogenetic analysis of cecal microbiota in chicken by the use of $16 \mathrm{~S}$ rDNA clone libraries. Microbiol Immunol 46, 371-382.

Lu, J., Idris, U., Harmon, B., Hofacre, C., Maurer, J. J. \& Lee, M. D. (2003). Diversity and succession of the intestinal bacterial community of the maturing broiler chicken. Appl Environ Microbiol 69, 6816-6824.

Marmur, J. (1961). A procedure for the isolation of deoxyribonucleic acid from microorganisms. J Mol Biol 3, 208-218.
Miller, G. L. (1959). Use of dinitrosalicylic acid reagent for determination of reducing sugar. Anal Chem 31, 426-428.

Miller, J. H. (1972). Experiments in Molecular Genetics. Cold Spring Harbor, NY: Cold Spring Harbor Laboratory.

Morotomi, M., Nagai, F. \& Sakon, H. (2007). Genus Megamonas should be placed in the lineage of Firmicutes; Clostridia; Clostridiales; 'Acidaminococcaceae'; Megamonas. Int J Syst Evol Microbiol 57, 16731674.

Nurmi, E. \& Rantala, M. (1973). New aspects of Salmonella infection in broiler production. Nature 241, 210-211.

Portrait, V., Cottenceau, G. \& Pons, A. M. (2000). A Fusobacterium mortiferum strain produces a bacteriocin-like substance(s) inhibiting Salmonella enteritidis. Lett Appl Microbiol 31, 115-117.

Sakon, H., Nagai, F., Morotomi, M. \& Tanaka, R. (2008). Sutterella parvirubra sp. nov. and Megamonas funiformis sp. nov. isolated from human faeces. Int J Syst Evol Microbiol 58, 970-975.

Shah, H. N. \& Collins, M. D. (1982). Reclassification of Bacteroides hypermegas (Harrison and Hansen) in a new genus Megamonas, as Megamonas hypermegas comb. nov. Zentralbl Bakteriol Hyg I Abt Orig C 3, 394-398.

Zhu, X. Y., Zhong, T., Pandya, Y. \& Joerger, R. D. (2002). 16S rRNAbased analysis of microbiota from the cecum of broiler chickens. Appl Environ Microbiol 68, 124-137. 